\title{
EXPERIENCIA MACBETH SIGLO XXI. EL MACBETH DE JUSTIN KURZEL
}

\author{
FLORA SAVASTANO
}

¿Quién es ese hombre ensangrentado?

Macbeth, I, ii.

Más de cuatrocientos años después de la escritura de sus obras, el fascinante mundo de Shakespeare nos sigue llamando a representar, casi por contagio. "Si algún autor se ha convertido en un dios mortal, es sin duda Shakespeare." (Bloom 2001: 28). Por lo que respecta a las adaptaciones cinematográficas, ya habían impactado las versiones de Macbeth de tres gigantes del cine, Orson Welles en 1948, Akira Kurosawa en 1957, Roman Polanski en 1971. En el siglo XXI, más precisamente en 2015, el australiano Justin Kurzel ha ganado su lugar en esta lista.

Con sólo dos largometrajes previos a este, el joven director se lanzó de lleno a recrear la atrapante "obra escocesa". Manteniendo el tiempo y el espacio del drama, la propuesta de Justin Kurzel contiene formidables escenas de batalla, imágenes que traen la lucha y el sufrimiento del verso a los ojos y oídos del espectador, como afirma Ward (2016), con la participación de grandes intérpretes que se mantienen fieles a la acción y la emoción, haciendo que esta propuesta cinematográfica de la tragedia más corta de Shakespeare sea una experiencia que por todos lados nos provoca y penetra nuestros sentidos.

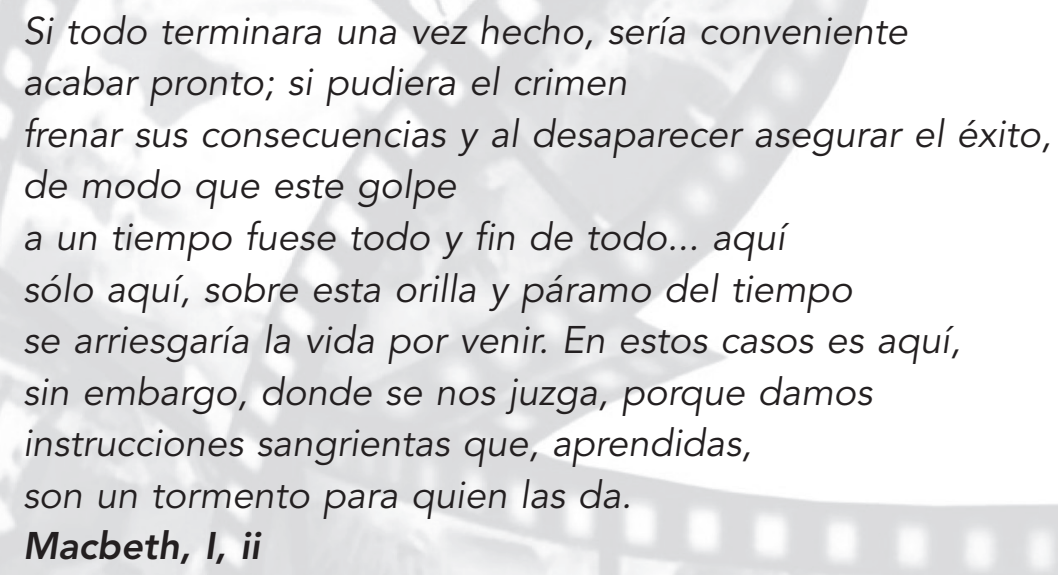

Macbeth, "el más obsesivo de todos mundos creados por Shakespeare" (Kott 2007:135), es la historia de un militar de siglo XI que mata para ser rey. Luego, atormentado, mata por 


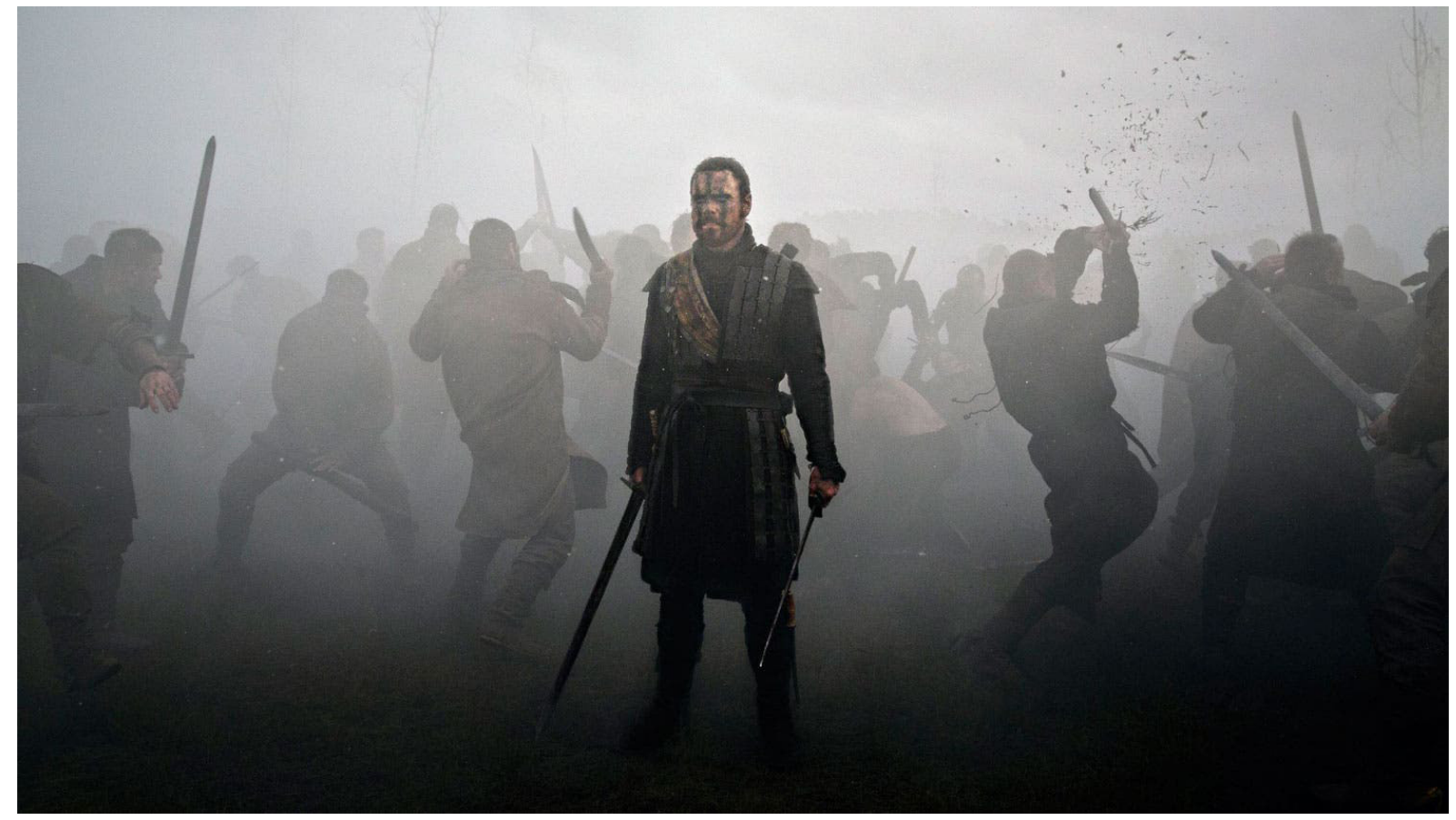

Macbeth. Justin Kurzel

paranoia. Macbeth trata un tema principal: el asesinato. La historia ha sido simplificada al máximo, reducida a una única imagen y una única división entre dos bandos: los que matan y los que mueren asesinados. Entre el paisaje aparecen las Weird Sisters (hermanas fatídicas), quienes comienzan esta obra proclamando: ¡Salve Macbeth, salve a ti que serás Rey! Éste, intrigado y movilizado, no se entrega al azar, ni al destino: "Puede convertirse en rey; así que tiene que convertirse en rey" (Kott 2007:131). En efecto, Lady Macbeth lo convence de ser él quien tome la daga, y que, como prueba de su virilidad, cometa el primer asesinato. Con este regicidio realizado por el protagonista, comienzan los delirios que convergen en matanzas despiadadas y crudas contra quienes él siente como una amenaza.

Como bien expresó Pavis (1987), la puesta en escena es siempre un discurso al lado del texto, no es una búsqueda redundante de significados ya existentes en él. Por lo tanto, en este diálogo con lo escrito, Justin Kurzel ha decidido dar ciertos giros ingeniosos en cuanto a los efectos visuales y estéticos. Además, trabajó intentando responder muchas de las preguntas que han atormentado a los lectores y al público de Shakespeare desde hace siglos (Behera y Dutta 2016). Por ejemplo, la habitual pregunta, ¿Lady Macbeth tuvo hijos?, es un tema que Justin Kurzel decide reforzar. Comienza la película con una escena trascendental: el velatorio del bebé recién fallecido de los Macbeth. Así es como se parte, desde la carencia. No hay ni habrá paternidad, habrá faltas. "Desde las primeras escenas Macbeth se define a sí mismo de forma negativa, no como quien es, sino más bien como quien no es" (Bloom 2001:141). La muerte del niño, que no forma parte del texto original pero se sugiere, fue un puntapié para encausar los comportamientos de estos personajes, desde un punto de vista totalmente acertado y poco reconocido, haciendo que la obra sea más relevante para su audiencia contemporánea.

Knights afirma, "una obra de Shakespeare es un poema dramático" (Knights, 1946: 6). Oír estos textos en su versión original, excelentemente transmitidos por los actores irlandeses, 
franceses, británicos y niños escoceses que protagonizan este film, es un deleite. Tenemos a un Michael Fassbender que captó la tristeza del personaje y el estado de duelo en el que dicho personaje está permanentemente envuelto, entregándonos miradas cabalmente genuinas de un hombre que, de ser un excelente líder guerrero sin temores, pasó a ser un traidor asesino, un hombre perturbado por su mente, que poco a poco va perdiendo el sueño (Ward, 2016). "Macbeth ha matado el sueño y ya no puede dormir. Nadie puede dormir en Escocia, ya no quedan sueños. Sólo pesadillas". (Kott 2007:135) Fassbender recibe una contrarréplica igualmente capaz y convincente, la de la aclamada actriz Marion Cotillard, que se convierte en Lady Macbeth y nos deja a todos conmocionados.

Con imponentes panorámicas naturales del territorio escocés que impregnan nuestra vista y nos deslumbran, Macbeth, como guerrero, es producto de un paisaje increíblemente brutal. Esta producción particular de Macbeth muestra cómo ese paisaje y otros factores externos influyen en la ambición de Macbeth. La forma en que el medio ambiente nos maldice o nos mira, o nos recuerda que somos pequeños, es algo a lo que nos sentimos muy cercanos. Los personajes se desmantelan en esta nueva producción. Hay algo inherentemente observable en los personajes que luchan por dar sentido a sus acciones y justificarlas (Behera y Dutta 2016).

Se suceden las escenas de guerra con efectos cámara lenta/rápida y mucha neblina. A lo lejos aparecen las hermanas fatídicas (ahora son cuatro). Entre juegos de colores, una nebulosa naranja abraza a Macbeth cada tanto, luego el gris y negro vuelven a predominar en las escenas. Entre la arquitectura medieval hay una suma de signos connotados que hablan. La puesta en escena dialoga con el texto y nos impresiona. Las imágenes tienen sonidos, sonidos que traen sensaciones. Las gaitas y violines entrelazados se oyen de fondo, suave pero siniestro. El diálogo que establece Justin Kurzel con el texto original es una propuesta que mezcla el clasicismo con lo innovador haciendo que esta película sea una gran "experiencia Macbeth siglo veintiuno".

\section{BIBLIOGRAFÍA CONSULTADA}

BeherA, G. \& DutTA, C. (2016). Of Children, Witches and the Problematic of Succession: Justin Kurzel's Macbeth en Literature and World Cinema (2015) 24-36. New Delhii, India: Authors press.

BLOOM, H. (2001). Shakespeare: La Invencion De Lo Humano. Bogotá, Colombia: Norma.

KNIGHTS, L. C. (1946). Explorations: Essays in criticism mainly on the literature of the seventeenth century. Londres, Inglaterra: London, Chatto \& Windus.

KOTT, J. (2007). Shakespeare, nuestro contemporáneo. Barcelona, España: Editorial Alba.

PAVIS, P. (1994). Del texto a la escena, un parto difícil. -en El teatro y su recepción. La Habana, Cuba: Casa de las américas.

SHAKESPEARE, W. (1606). Macbeth. Barcelona, España: Orbis S.A. 1982

WARD, S. (2016). Sound and Fury Ambition, Absence and Anger in Justin Kurzel's Macbeth". Screen Education, 82, 24-31. 